\title{
Uwagi o pojęciu państwa i suwerenności
}

\author{
DOI: $10.35757 /$ CIV.2010.12.05
}

Nie tylko Ameryka jest wyjątkowa. Wyjątkowość Europy kontynentalnej czasów nowożytnych polega na tym, że w jej kulturze pojawiły się wówczas trzy pojęcia mające fundamentalne znaczenie dla ładu życia zbiorowego oraz jego form - pojęcia państwa (i suwerenności), polityki i prawa. Pojęcie państwa wyróżnia się wśród nich, ponieważ (1) powstało u progu nowożytności, podczas gdy dwa pozostałe sa o wiele starsze, a ich historia sięga starożytności; (2) jest ściśle związane $z$ Europa porenesansową, poreformacyjną, określa charakterystyczną dla niej postać ustroju politycznego, gdy tymczasem polityka i prawo to pojęcia ogólnohistoryczne. Choć są one w historii prawie wszechobecne, w każdej organizacji społecznej, w każdej postaci cywilizowanego życia, to jednak od XVI wieku zyskuja istotnie nowe, swoiste znaczenie, zyskują właśnie dlatego, że stają się ściśle związane $z$ pojęciem nowym, pojęciem rzeczy nowej, pojęciem państwa.

Te trzy pojęcia, choć nie pojawiaja się w swej nowej postaci dosłownie równocześnie, są ze sobą związane, nie można wyjaśnić któregokolwiek z nich nie odnoszac się do pozostałych. Łączy je ponadto szczególna cecha: sa niejako puste, „formalne”; sa pojęciami sfer wyraźnie odrębnych, ale bardzo trudno określić rodzaj,

Pawet Kaczorowski - filozof, doktor habilitowany, profesor Uniwersytetu Kardynała Stefana Wyszyńskiego w Warszawie, docent w Instytucie Studiów Politycznych PAN. Redaktor naczelny „Civitas. Studia z Filozofii Polityki” (od 1997 r.). Autor m.in. Państwo w czasach demokracji. Rudolf Smend i Carl Schmitt o istocie porząlku państwowego Europy kontynentalnej (2005). 
naturę tego, co do nich należy, co je wypełnia. Do dyskursu zostały wprowadzone bez definicji, zrodzone przede wszystkim $z$ bieżącej potrzeby nazwania, określenia czegoś, $z$ potrzeby nazwania tego, co nagle pojawiło się $\mathrm{w}$ świecie społecznym, a nie $z$ refleksji.

Dlatego od czasów ich wprowadzenia nie ustaja próby wyjaśnienia ich istoty.

\section{O pojęciu państwa}

Być może istotnie żyjemy w „międzyepoce”, gdyż uwagi na temat państwa trzeba zaczać od postawienia pytania: jaka treść ma obecnie to pojęcie? Czy posługiwanie się nim, niegdyś oczywistym, niesie dziś jeszcze możliwość orientacji w świecie polityki? Czy każdy współczesny ustrój polityczny jest ustrojem państwa? Czy jest to pojęcie realności historycznej, czy też ideału, wzorca? Czy państwo jest pojęciem używanym na co dzień, czy już tylko „odświętnym”? Czy jest pomocnym narzędziem opisu, obiektywnym, wspólnym, czy też pojęciem stronniczym, związanym $z$ opcja polityczną? Czy odpowiada ono dzisiejszej rzeczywistości politycznej, czy też już nieodwołalnie należy je zastapić pojęciem „system polityczny", które zdaje się lepiej pasować do wielości, rozmaitości, relacyjności, cech charakterystycznych - jak się sądzi - dla dzisiejszego życia politycznego?

Czy my, Polacy, posiadamy dzisiaj wyraziste pojęcie państwa, odziedziczone, zachowane być może jeszcze $z$ okresu międzwojennego, kiedy było ono mocno akcentowane, obecne w życiu publicznym i tak wyraźnie zapisane w przepisach konstytucji z 1936 roku? Czy tylko ciąży nam wspomnienie opresywnej „państwowości PRL-u", państwa-przeszkody, państwa-intruza, państwa-marnotrawcy? Czy mówiąc „państwo”, odwołujemy się do tradycji własnej, do pamięci o wcześniej podejmowanych wysiłkach, może zwłaszcza wysiłkach któregoś $z$ pokoleń, czy też majaczy nam tylko przed oczami niewyraźnie państwowość krajów Europy 
Zachodniej, do której aspirujemy? Czy doświadczenie rewolucji Solidarności może, czy też nie, stanowić mit założycielski, etyczno-polityczny fundament państwa polskiego lub może raczej mit republikańskiej wspólnoty?

Można $z$ przekonaniem twierdzić, że brak ustalonych pojęć w debacie publicznej, w nauce, a może zwłaszcza w polityce, stawia nas przed koniecznością świadomego, przemyślanego wyboru koncepcji ustroju politycznego, tradycji państwowej, którą będziemy praktykować w działaniu i kultywować w refleksji. Jest to imperatyw, jeśli nie chcemy, aby decyzja $\mathrm{w}$ tej kwestii zapadła samoistnie, za naszymi plecami, po cichu ustalona przez „tendencje współczesności”, „determinanty cywilizacyjne” albo „procesy globalizacji”.

Starając się wyjaśnić pojęcie państwa, można zastosować zabieg symplifikujacy, może nawet demaskatorski, i przyjąć, że mamy oto do czynienia jedynie $z$ pojęciem sumarycznym, pojęciem zbioru, na który składają się konkretne elementy. Obejmuje on przede wszystkim władzę państwowa i budowany przez nia porządek oraz ludność zamieszkująca określone przez państwo terytorium. (Te elementy wymienia słynna definicja państwa Georga Jellinka). Ale zaraz można tę dekonstrukcję poprowadzić o wiele dalej. Władza państwowa rozpada się przecież na inne składniki, jeszcze bardziej, zdawałoby się, uchwytne empirycznie, bliższe obywatelowi niż ona sama, sama w sobie. Nietrudno je wymienić. Sa to, przede wszystkim, poszczególne instancje władzy, urzędy, agendy, inspekcje; podlegaja one prawu, maja określone kompetencje, procedury, podejmuja ukierunkowane działania, doraźne, okresowe, permanentne. $Z$ kolei na porządek państwowy składaja się oddzielne domeny zmieniajacych się, prowadzonych przez owe instancje polityk, wdrażających prawo, efekty ich działan, rzeczowe regulacje różnych sfer życia społecznego, przedsięwzięcia organizujące, wspomagające, inicjujące... Osobna poniekąd sferą działania państwa jest stanowienie prawa, a następnie ezgekwowanie porzadku prawnego, a także uczestniczenie i zarazem monitorowanie życia politycznego. Sa to sprawy podstawowe, z którymi kojarzy się pań- 
stwo, o tych składnikach struktury państwa najczęściej przecież się mówi, słyszy, czyta, to one skupiaja na sobie uwage mediów, a także ich odbiorców.

Ale czy to wszystko, czy państwo można sprowadzić do wielości takich cząstkowych, konkretnych elementów, czy państwo to tylko gigantyczne urządzenie, które ma pewnie i skutecznie funkcjonować, by ułatwiać, usprawniać, ulepszać nasze życie, podnosić jego standard, racjonalizować, zapewniać rozwiąywanie problemów społecznych, eliminację zjawisk niepożądanych?

Można stwierdzić, że takie pytanie o państwo brzmi jak klasyczne pytanie metafizyki: czy rzecz się sprowadza do swych empirycznych, wskazywalnych, policzalnych cech, czy też u ich podłoża znajduje się coś jeszcze, coś podstawowego, w czym one tkwia, co je utrzymuje - substancja? Albo inaczej: czy całość jest tutaj tylko suma, zbiorem części, czy też czymś więcej, czymś ponad to, co je ogarnia i wyznacza każdej miejsce?

Zwłaszcza to drugie pytanie można uznać tu za odpowiednie, ponieważ sytuując w centrum problem całości i części, wydaje się ono bardziej adekwatne do rodzaju rzeczywistości, jaka państwo soba przedstawia - rzeczywistości hierarchicznej, złożonej, integralnej. Nadto pytanie to sięga do tradycji metaphysica specialis, która podejmowała rozważania na temat nie bytu jako takiego, ale bytów, idei, podstawowych: człowieka, świata i Boga. Do każdego z nich zaś państwo w swej historii bywało przyrównywane. Było pojmowane jako „wielki człowiek” albo artificial reason, jako własny świat życia narodu, a także w analogii do Boga i Opatrzności.

Czy niedosyt poznawczy, jaki pozostawia „reistyczna” odpowiedź na pytanie o istotę państwa jest uzasadniony? Czy istnieja podstawy, by odpowiedź taka odrzucić i poszukiwać innej? Kwestie, które się w tym miejscu pojawiaja mogłyby zapewne stanowić dowód na to, że hermeneutyczna teoria pytania jest nadal aktualna. Wszelako zamiast powracać do niej, wolno sądzić, iż mimo wątpliwości, opierając się na przeświadczeniu o jego sensowności, można po prostu postawić pytanie o to, czy istnieje „substancja” 
państwa. Czy w realnej strukturze państwa tkwi jakiś pierwiastek „idealny”, płaszczyzna meta? Czy „metafizyka” państwa ma swój przedmiot? Jeśli nawet pytanie to miałoby być wyrazem $z$ góry przyjętych supozycji, to bronić się przed takim zarzutem można wskazując, że supozycje te nie sa widocznie nieuzasadnione, skoro przedstawiciele zachodnich społeczeństw budujących państwo rozwinęli refleksję jego dotycząca, sformułowali poglądy, teorię państwa, która, w porównaniu ze współczesna politologią, miała charakter głęboko metafizyczny - w najlepszym sensie tego słowa - oraz dowodziła istnienia tego, co filozoficzne w naukach, w tym przypadku w naukach społecznych.

Co stanowiło - wedle tych poglądów - substancje państwa? Odpowiedzi były rozmaite: les politiques traktowali państwo jako fundatora i gwaranta pokoju społecznego, dla Filipa II substancja państwa było chrześcijaństwo, dla kardynała Richelieu była to racja stanu rozpoznawana dzięki arcana imperii, wedle teoretyków absolutyzmu oświeconego państwo było abstrakcyjna machina machinarum, dla XVIII-wiecznych torysów - organicznym tworem powstałym w toku życia społeczeństwa. Reprezentanci wczesnego niemieckiego konstytucjonalizmu postrzegali państwo jako organizm, a Klemens von Metternich - jako wytwór organicznego rozwoju, nawarstwienie tradycji wspólnotowych i dynastycznych, powinności stanowych i więzów lojalności grupowej. $Z$ kolei, gdy Benjamin Constant podkreślał znaczenie wolności i praw jednostki, Lorenz von Stein pojmował państwo jako państwo socjalne, zaś Robert von Mohl i Otto von Gierke - jako państwo prawne, w odmienny sposób je interpretujac. W drugiej połowie XIX wieku i na początku wieku XX poglądy na państwo - o wiele bardziej niż wcześniejsze zideologizowane - ukazywały je na przykład jako zinsytytucjonalizowana władzę posiadającego siłę polityczną narodu (Otto von Bismarck, Heinrich von Treitschke), jako władzę republikańskiego demosu (Léon Gambetta), konserwatywnych republikanów (Louis Adolphe Thiers) albo rewolucyjnej partii (Włodzimierz Lenin). W XX wieku Georg Jellinek rozwinał swa dwuaspektowa, prawno-społeczna te- 
orię państwa, Max Weber zaś - teorię państwa jako przedsiębiorstwa (Anstalt) w którym najważniejsze sa także środki - ale nie produkcji, tylko przymusu. Dla Carla Schmitta substancja państwa była polityczność podmiotu zbiorowego, dla Rudolfa Smenda - integracja nadająca społeczeństwu tożsamość zbiorowa. Hermann Heller podstawę fundujacca państwo widział w suwerennej władzy, stanowiącej porządek prawny, dla Ericha Kaufmanna zaś taka podstawą był aksjologiczny porządek życia zbiorowego, zakładany jako metapłaszczyzna i konkretyzowany w normach przez prawo stanowione. Jeszcze inne poglądy dotyczace natury państwa mieli José Ortega y Gasset, Friedrich Meinecke, Heinrich Triepel, Hans Kelsen, Maurice Hauriou czy Léon Duguit. Trzeba przypomnieć, że wszystkie te stanowiska dotyczyły państwa jako historycznej realności, która była przedmiotem ich poznania.

Pytanie o istotę państwa może jednak dziwić, gdyż państwo jawi się wtedy jako rzecz nieznana, wielka niewiadoma, przedmiot dociekań, a przecież byt państwowy jest tworem człowieka, tworem jego racjonalnej działalności, systematycznej, planowej. Czyżby człowiek nie wiedział co stworzył, czego dokonał, co powołał do istnienia? Być może państwo powstaje na podobnej zasadzie jak perła w perłopławie: zamysł państwowotwórczy, świadomy, przemyślany, jak drobina piasku otacza się swoistą treścia, obudowuje tym, co przynoszą doświadczenie, los i czas, wydarzenia i sytuacje, i stanowi już nową, inną całość. A może państwo - jak czynił to Jakob Burckhardt - trzeba przyrównać do dzieła sztuki, Kunstwerk, które jest dokonaniem człowieka, ale zarazem czymś po wielekroć więcej, w czym wkład działań twórcy jest trudny do ustalenia, a on sam występuje raczej jako medium szczególnego procesu, procesu kreacji, którego wytwór pojawia się jako byt jedyny w swoim rodzaju, a nie kopia, urzeczywistnienie wprzódy znanego projektu. Państwo nie jest zastanym obiektem, przedmiotem; aby to podkreślić, stosowano porównanie $z$ organizmem. Państwo to organizm. Ma swoja entelechię - zasadę życia, która pozwala mu istnieć, poprzez stałe odradzanie się, odtwarzanie. Dlatego zdania 
takie jak „państwo jest...”, „państwo zakłada...”, „państwo stanowi..." trzeba rozumieć nie jako opis własności zastanego w świecie przedmiotu, ale opis bytu, który ma wewnętrzna pulsujaccą zasadę, czyniąca go takim, określająca jego racjonalność.

Choć elementy państwa są dane, to jednak nie same przez się, nie istnieja $z$ natury ani nie zastajemy ich $\mathrm{w}$ społeczeństwie. Sa ustanowione... przez samo państwo. A zatem państwo jest bytem samoustanawiającym, jest czymś więcej niż to, co ustanowione, ma inną jeszcze płaszczyznę. Państwo, w głębszym znaczeniu, jest siłą emanująca, która stoi w tle i wyłania $z$ siebie elementy nadające jej pełna, realna postać; jest potencją, która nadaje sobie formę, czymś abstrakcyjnym, co samo się konkretyzuje.

Państwo nie tylko samo ustanawia składniki swej struktury, ale również samo musi zapewnić im trwanie, utrzymywać je w istnieniu. Ustrój nie istnieje $z$ natury, a więc nie jest też $w$ naturalny sposób zagwarantowany, nie wystarczy go tylko w mechaniczny sposób odtwarzać. Państwo zachowuje swój byt dzięki temu, że... go zachowuje, że potrafi tego dokonać, wykazuje siłę i determinację. Jest bytem autorefleksyjnym $\mathrm{w}$ tym sensie, że do jego zadań należy samoobserwacja, monitorowanie otoczenia, w jakim istnieje, by je kontrolować, by zapewnić warunki swej możliwości, by maksymalnie zabezpieczyć swą egzystencję, która nie ma samoistnej gwarancji istnienia $\mathrm{w}$ historii.

Jeśli nawet państwo można przedstawić jako meganarzędzie, jako wielki mechanizm, to działając całościowo, wielostronnie, w sposób pełny, stanowi ono zarazem - jak twierdził zapomniany dziś klasyk Rudolf Kjellen - swoista postać życia, życia podmiotowego. Zabezpieczenia, standaryzacje, usprawnienia, jakie wprowadza, tworza razem, można się domyślać, wartość dodatkowa, składają się na całość będącą czymś więcej i czymś innym niż prosta suma części, całość mająca charakter swoistej formy egzystencji zbiorowej, egzystencji integralnej. Jednostka może tego doświadczać na co dzień w procesie szczególnego metabolizmu informacyjnego zachodzącego między nia a otoczeniem, dzięki wie- 
lości ułamkowych spostrzeżeń, wrażeń, refleksów, które rejestruje „podprogowo" albo mniej lub bardziej świadomie; one sedymentują się w niej, utrwalaja, kształtuja i ja, i jej oczekiwania, kreuja jej polityczny Lebenswelt.

Państwo jest synonimem jedności i całości, o czym świadczy choćby określenie „państwo w państwie”, wskazujące na zasadę państwa oraz to, co zasadzie tej przeczy, wyłamuje się $z$ niej. Określenie to, powszechnie używane, oparte jest na przekonaniu, że państwo słusznie pretenduje do nadrzędności, do tego, by stanowić powszechny punkt odniesienia, i dlatego ignorowanie tej wyłącznej kompetencji państwa jest próbą nieuprawnionego podszywania się pod nie, tworzenia sytuacji dwuwładzy, wywoływania chaosu. Jedność i całość były istotowymi przymiotami porządku państwowego, zwłaszcza w czasach nowożytnych, gdy porządek ten budowany był wyraźnie jako przeciwieństwo i przezwyciężenie rozczłonkowanego, wieloinstancyjnego, sfragmentaryzowanego ustroju feudalnego, feudalnej poliarchii. Wola państwowotwórcza przejawiała się wówczas $\mathrm{w}$ dążeniu do wyodrębnienia terytorium i zbiorowości, które niepodzielnie poddane byłyby jej zwierzchności oraz stanowiły tworzywo. Do skojarzenia jedności i całości jako podstawowych własności państwa nawiązuje także sposób kreślenia mapy politycznej, na której każda państwowość zostaje zaznaczona zawsze odrębnym, jednolitym kolorem, takim samym na całym jej terenie.

O państwie mówi się często w relacji do czegoś innego, mówi się jako o członie opozycji (na przykład państwo i gospodarka, państwo i kultura, państwo i społeczeństwo, państwo i naród, państwo i Kościół). Sa to powszechnie stosowane, ogólne, podręcznikowe kategoryzacje, dające podstawę rozważaniom filozoficznym i dociekaniom naukowym, takim jak choćby klasyczne dziś Weltgeschichtliche Betrachtungen przywoływanego już Jakoba Burckhardta, w których wykłada on swą naukę o trzech potencjach dziejowych - religii, państwie i kulturze - oraz o ich wzajemnych zależnościach i uwarunkowaniach. Państwo jest czymś różnym 
od kultury, gospodarki, sztuki, ale zarazem, z istoty swej, odnoszącym się do nich. Nie jest bytem odrębnym w tym znaczeniu, $\dot{z}$ e istnieje poza nimi oddzielnie, osobno; jest $z$ istoty swej władzą i porzadkiem, które „rozpościerają się” na tych dziedzinach, ale nie stapiają $z$ nimi.

Jeśli te przeciwieństwa mają istotne znaczenie przedmiotowe, znaczenie dla ogólnego przynajmniej określenia miejsca i roli państwa w najszerzej, tj. socjologicznie pojmowanym życiu społecznym (socjologia nie przyjmuje założenia o rozdziale państwa i społeczeństwa), to państwo musi być - w swym pojęciu - jednościa i całością, nie zaś tylko maszynerią części, z których każda funkcjonuje $\mathrm{w}$ swoim zakresie, a razem stanowi wraz $z$ innymi uporzadkowany zbiór. Musi, na głębszym poziomie, posiadać integralność, swoja substancję, skoro jest - a tak jawi się w tych opozycjach - czymś jednym wobec substancjalnych dziedzin życia społecznego, z których każda jest inna, różna od pozostałych; czymś całościowym wobec dziedzin, których jest wiele. Przeciwstawienia te niczego jeszcze nie konstatuja stanowczo ani nie dowodza, świadcza jednak o sposobie myślenia, wyobrażania sobie państwa, który, jeśli odzwierciedla „naturalna”" tendencję, jeśli nie jest sposobem odruchowym ani dowolnym, można uznać za zasadny trop myślowy, przesłankę dociekań, które dotrą do kryjących się za nim rzeczowych racji.

Zapewne, by ujrzeć inne wymiary istnienia państwa, potrzebna jest określona perspektywa. Daje ja, między innymi, historia. Zwłaszcza bowiem, gdy patrzy się na dzieje państwa, można dostrzec, że nie sprowadza się ono do "tych oto" konkretnych swych elementów. Te przecież zmieniają się, przekształcaja, rozbudowuja, a państwo trwa, pozostaje, przeistacza się; ciagłość jego istnienia zostaje zachowana. Jest więc $\mathrm{w}$ nim coś, co leży u podstaw i nie ulega zmianie, substancja, która ukazuje się pod różnymi postaciami. Tożsamość państwa jest czymś poza jego konkretnymi wcieleniami ustrojowymi, lecz nie opiera się raczej na tożsamości jakiegoś elementu „materialnego”: narodu, terytorium, kultury... 
Wszystkie te czynniki maja znaczenie dla trwania państwa, ale podstawę musi tu stanowić coś, co pozwala dynamicznie kształtować owe postacie ustrojowe, nieokreślony élan vital zbiorowości, który umożliwia podejmowanie ryzyka zmian, przezwyciężanie nieoczekiwanie pojawiających się przeszkód, mobilizowanie sił w obliczu niebezpieczeństw, znajdowanie słusznych rozwiąań. Dlatego tak ważna jest polityka historyczna, która pokazuje, że trwanie państwa nie jest dziełem przypadku, zbiegu okoliczności, ale osiagnięciem, rezultatem przemyślanych poczynań, owocem zbiorowego wysiłku, wysiłku pokoleń.

Państwo jako synonim całości, jedności nieredukowalnej do prostej sumy elementów, $z$ których się składa, jest czymś abstrakcyjnym, czymś meta... Musi ono akcentować ten wymiar swojego istnienia, podkreślać, że on istnieje i jest tym, co w państwie najważniejsze, bo centralne. Abstractum państwa, niewidoczne, wychodzace na jaw dopiero w refleksji, bywa niedostrzegane, może zanikać w potocznej percepcji, trzeba więc o nim przypominać. Dlatego tak ważne sa symbole, znaki państwa - godło, hymn, barwa - służące temu, by podkreślać i utrzymywać świadomość państwa jako czegoś więcej... niekonkretnego, ale realnego.

Państwo musi działać dla idei, dla „swojej” idei, bo w pewnej mierze jego istnienie jest właśnie istnieniem „idei”; musi zaznaczać swoja obecność, swój byt meta, zwłaszcza poza obszarem bezpośrednio poddanym kontroli, objętym jego ewidentna działanością. Musi się pojawiać właśnie tam, gdzie wydaje się jak gdyby nieobecne i przez to być obecne tym bardziej, chociażby po to, aby bronić najodleglejszego skrawka terytorium i każdej jednostki - swego obywatela, który na przykład zaginął. Oczywiście takie działania maja znaczenie „państwowe” tylko wtedy, gdy nie sa przeprowadzane ad hoc i na pokaz, ale przystaja do sprawnej i konsekwentnej działalności państwa na co dzień. „Idea” nie zastapi materialnego porząlku państwa; przeciwnie, tylko sprawne i konsekwentne działanie państwa na co dzień można traktować jako przejaw państwa i jego idei. 


\section{O pojęciu suwerenności}

$Z$ pojęciem państwa ściśle związane jest pojęcie suwerenności; jest ona pierwszym elementem struktury państwa, która teoretyk państwa identyfikuje w materii badawczej, jakiej dostarcza mu historyk. Do struktury tej należy także między innymi przestrzenny charakter państwa, przymusowa doń przynależność, rozdział na sferę publiczna i prywatna, legitymizacja władzy. Choć w piśmiennictwie politycznym pojęcie „suwerenność" pojawiło się - tylko $\mathrm{w}$ formie przymiotnikowej - $\mathrm{w}$ późnym średniowieczu, $\mathrm{u}$ takich autorów jak Bartolus z Sassoferato i Sylwiusz Piccolomini (późniejszy Pius II), to jednak głównym jego XVI-wiecznym twórca i teoretykiem był Jean Bodin, podówczas deputowany „trzeciego stanu” do Stanów Generalnych $z$ okręgu Blois. W praktyce politycznej zapewne wcześniej, zaś w myśli państwowej, politycznej właśnie od czasów ukazania się jego pracy Sześć ksiag o Rzeczypospolitej, pojęcie "suwerenność" uznawane jest za rdzeń koncepcji państwowości, a suwerenność za nieodłączną cechę państwa. Od tego czasu można było twierdzić, że zdanie "państwo jest suwerenne” jest zdaniem analitycznym.

Suwerenność - wewnętrzna, na której koncentrował się Bodin - Hugo de Groot (Grocjusz) nieco później analizował głównie suwerenność zewnętrzna - wskazuje, w inny sposób, na samoistny charakter bytu państwowego; łączy się także $z$ cechami zasadniczymi porządku państwowego, jakimi sa jedność i całość, ponieważ władza państwowa i tworzony przez nia ład maja konstyutuować jedność społeczeństwa (tak w wiekach XVI-XVIII) lub ją reprezentować (tak w wieku XIX).

$\mathrm{W}$ bogatej literaturze, która powstała od czasów pojawienia się dzieła Bodina, problematyka suwereności była omawiana pod wieloma zasadniczymi względami. Można sformułować całą listę zagadnień, które teoria suwerenności państwa zalicza do centralnych. Jest to, po pierwsze, kwestia kwalifikacji samego pojęcia: czy jest ono pojęciem prawniczym, politycznym, czy politologicznym. 
Z kolei już u Bodina wymieniane były pozytywne właściwości suwerenności, a także jej właściwości negatywne. Suwerenność była przypisywana władzy monarchicznej, ale jeszcze wcześniej, i tylko w teorii, przysługiwała także władzy ludu; wszelako można zasadnie pytać, czy w obu przypadkach chodzi o tę samą suwerenność. Następna, często dyskutowaną kwestia jest przynależność suwerenności: czy przysługuje ona samej władzy państwowej, podmiotowi władzy, czy państwu. Jeśli władzy, to czy jest ona istotą władzy państwowej, czy też tylko jej istotna właściwością; jeśli państwu, to czy daje to podstawę do uznania, obok zasady suwerenności, zasady podziału władzy. Wreszcie trzeba pamiętać i o tym, że pod koniec XIX wieku niektórzy teoretycy (np. Hans Krabbe) zaczęli mówić o suwerenności prawa zamiast o suwerenności państwa.

Dość powszechnie uważa się suwerenność za przymiot władzy państwowej - w ten sposób przedstawiał ja jeszcze Bodin. Znaczy to, że tak określona władza państwa jest abolutna, najwyższa, nadrzędna, niezależna. Suwerenna władza państwowa jest władza sui generis, dlatego pierwotna, że nie wynikajaca $z$ niczego poza i ponad państwem. Niczego bowiem ponad nim już nie ma, żadnej wyższej instancji. To właśnie samo państwo bąź jego władza, jest - separatus et imperet - poza i ponad społeczeństwem, jego instancjami, lokalnymi, korporacyjnymi, terytorialnymi, jego stowarzyszeniami, wspólnotami, organizacjami, obywatelami. Suwerenna władza i porządek - to znaczy własna, nie będąca epifenomenem, funkcją czegoś innego, na przykład narodu, opinii publicznej, gospodarki, Kościoła. Władza ta ma szczególne kompetencje: wskazywania dziedzin i spraw, które reguluje, ostatecznego rozstrzygania kwestii politycznych, spornych, ma monopol na stosowanie legalnego przymusu.

Ponieważ suwerenność konkretnie przejawia się w działaniach władzy państwowej, państwa, więc jej warunkiem jest to, co te działania umożliwia: niezależna od społeczeństwa, powołana przez samo państwo administracja i policja - instrumentarium władzy suwerennej. Właśnie dzięki niemu państwo może podejmować 
niezależne, całkiem własne działania: może je podejmować bez względu na czyjąkolwiek zgodę lub jej brak, może też wyznaczać cele tych działań wedle własnego uznania.

Dla posiadania suwerenności istotna jest również potencja państwa (demograficzna, terytorialna - geopolityczna, gospodarcza, kulturowa i cywilizacyjna). Dzięki niej jest ono, do pewnego stopnia, samowystarczalne, może w jakiejś mierze samodzielnie zaspokoić swoje potrzeby i zapewnić swoim obywatelom pewien standard życia.

W tym kontekście istotne znaczenie ma także siła militarna, umożliwiająca, jeśli jest to konieczne, przeprowadzenie działań tworzacych fakty polityczne, które - w wymagającej tego sytuacji - „wymusza” uznanie suwerenności państwa przez społeczność międzynarodową oraz konsekwentnie będą umożliwiać obronę posiadanej niepodległości.

Wszystko to sa zagadnienia istotne, wszelako nie one nastręczaja najwięcej trudności $\mathrm{w}$ toku analizy pojęcia suwerenności. Prowadza natomiast do postawienia pytania właśnie o samą istotę władzy suwerennej, postawienia po to, by odpowiedź na nie uczyniła to pojęcie jasnym, uczyniła jasnym jego realne znaczenie nie tylko dla państwa jako struktury administracyjnej, nie tylko dla państwa polityków i urzędników, ale dla państwa jako formy politycznego bytu całej zbiorowości, dla państwa jako wspólnego dobra społecznego. Tylko wtedy profilowanie polityki państwa, porząku państwa wedle logiki władzy suwerennej nie będzie publicznie odbierane jako nakładanie opresywnych rygorów lub dyscyplinowanie obywateli.

Państwo to władza, ludność, terytorium; władza państwowa stanowi, wprowadza, organizuje, kontroluje, sadzi... Do jej zadań należy hierarchizowanie celów i ustalanie priorytetów zadań, osiaganie zgody społecznej, zachowywanie równych warunków dla podmiotów i egzekwowanie prawa, gwarantowanie ładu i porządku publicznego, tworzenie kanałów połączeń i komunikacji w sieci społecznej. 
Szczególny charakter suwerennego państwa polega na tym, że jest ono tym, co zarazem indywidualne i ogólne, jest tym oto konkretnym państwem, jednym $z$ wielu, ale jednocześnie porządkiem ogólnym, samoistnym, poniekąd „światem w sobie”. Dlatego właśnie państwowość można opisywać nie tylko w sposób empirystyczny, na podstawie badania obserwowanych cech, ich podobieństw i dokonywanych w ten sposób generalizacji - jak czynił to Max Weber - ale można ją opisywać także „eidetycznie”, „fenomenologicznie", badajacc - w każdym przypadku taką sama - ogólność, ogólną formę życia, która jest, jej wewnętrzna strukturę i zasady, jak czynili to Rudolf Smend, Erich Kaufmann czy Carl Schmitt.

Funkcjonowanie „dobrego” państwa nie polega na podejmowaniu działań sporadycznie, przypadkowo i doraźnie, ale na działaniu „na zasadzie”, wedle zasady, która państwo samo określa i ustanawia. Oznacza to, że państwo nie jest tylko czymś, co po prostu jest i działa, lecz kieruje się racja, ale nadto jeszcze własna racją, przez siebie ustalona; działa wedle prawa, ale własnego prawa. Własne prawo państwa, własna racja państwa to znaczy prawo, racja odnosząca się do państwa, dotycząca państwa, ale też prawo, racja, która państwo samo kreuje. Dzięki temu państwo jest tworem samosterownym i samoodnoszącym się do siebie, dlatego bywało i jest przyrównywane do organizmu albo traktowane jako mające osobowość (prawna).

Państwo suwerenne można inaczej określić jako państwo miarodajne. Mając zasadę swego istnienia w sobie samym, zapewniajac sobie własne doktrynalne, racjonalne podstawy (legitymizację), może ono równoważyć na tej podstawie wszelkie mające doń odniesienie wymagania, żądania i postulaty: religii, antropologii, etyki, filozofii i nauki. Ich zasady i racje zderzaja się $z$ suwerenna racja własna państwa. W ten sposób powstałe stanowiska moga toczyć spór, wzajemnie się negować, ale także uzupełniać, wzajemnie zapośredniczać i wzbogacać.

Suwerenność, co pokazuje już w swym dziele Bodin, nie jest przymiotem każdej władzy politycznej ani każdego ustroju. Pojawia 
się $\mathrm{w}$ pewnym momencie dziejów, dziejów Europy, a moment tego pojawienia się nie jest bynajmniej dla treści pojęcia obojętny. Decydujące sa ówczesna sytuacja i okoliczności historyczne, społeczne, kulturowe, religijne; to one rodza potrzebe stworzenia państwa - suwerennego porządku politycznego. Pojęcie „suwerenność władzy państwowej" pojawia się w odpowiedzi na pytanie o fundament ładu społecznego, o to, na czym opiera się ład społeczny. W średniowieczu suwerenność władzy nie istniała, gdyż w tamtych warunkach nie było na nia miejsca, nie istniał ogólny porządek publiczny jako całościowy, jednolity, świadomie ustanowiony. Doczesny sposób życia małych grup ludzkich, małych społeczności, z których składało się „społeczeństwo"1, był ograniczony przez dominujace warunki środowiska, determinowany przez naturę; to ona określała porządek, wyznaczała ludziom miejsce, stanowiła dla nich miarę. Można stwierdzić, iż to natura była wtedy suwerenna, to znaczy miarodajna dla życia ludzi, ład życia zbiorowego był jej częścia.

Dopiero w czasie kryzysu w XVI wieku pojawiła się gwałtowna potrzeba wprowadzenia stanu (cywilnego), ustanowienia porządku, pokoju i prawa, ustanowienia świadomego i celowego. Państwo to właśnie sztucznie wprowadzony stan, status (der Staat, l'état, estado, lo stato, state) - sztuczny, zaprowadzony, utrzymywany, istniejący dzięki czemuś, a nie samoistnie. Stąd pytanie o to, co go utrzymuje, o podmiot, o konstytuujaca go instancję.

Stan ten jest „sztuczny”, bo wprowadzony świadomie, celowo, w konkretnym momencie dziejowym - w momencie kryzysu i w celu przezwyciężenia kryzysu. Ale stan ten zostaje utworzony także dzięki temu i dopiero wtedy, gdy zasadę trwania zaczyna zastępować w ludzkim życiu zasada rozwoju, gdy człowiek jest już zdolny wykroczyć ponad ograniczenia natury, ponad przyrodę, i może zacząć tworzyć więcej niż to potrzebne, by tylko przeżyć. Państwo, suwerenna władza powstały wtedy, gdy pojawiła

O zasadności uznawania pojęcia „społeczeństwo" za pojęcie ogólnohistoryczne piszę w o pojęciu społeczeństwa $i$ jego historii (w druku). 
się pewna „wartość dodatkowa” zbiorowego działania ludzkiego, gdy człowiek odkrył w sobie nowe możliwości, zyskał swobodę działania i kreowania, rozwiną i wzbogacił swoje życie społeczne, gospodarcze, kulturalne, religijne, zaczał wypracowywać więcej niż to konieczne do zaspokojenia podstawowych potrzeb. Życie społeczne bogatsze i wielowymiarowe stwarza szanse i zagrożenia zarazem $^{2}$. Stwarza szanse, gdyż stanowi tworzywo, materię kształtowania alternatywnych form bytu społecznego, realizacji możliwych jego racjonalnych projektów. Stwarza też zagrożenia, bo oznacza wyjście $z$ dotychczasowych, znanych, utrwalonych kolein życia, odejście od egzystencji małych wspólnot ku formom stowarzyszenia lub raczej właśnie społeczeństwa; oznacza pojawienie się wielości sprzecznych racji, prawd, ideałów. Takie są obiektywne przesłanki istnienia państwa, warunki, które umożliwiają i wymagaja pojawienia się władzy i władcy nowego typu, suwerena, księcia, jakiego portretuje Machiavelli, księcia, który, jak artysta, kreuje $z$ danego materiału społecznego formę bytu politycznego.

Czym się wyróżnia władza suwerenna? Tym, że może na poddanych nakładać obowiązki, że może im przepisywać prawa. Ich posłuszeństwo nie wynika ani $z$ umowy, zapewnienia, ani $z$ prawnonaturalnej idei ładu, ani ze wspólnego życia w jakiejś wspólnocie. Polega ono na zwierzchności władzy suwerena oraz na bezwarunkowym poddaniu się jednostki - poddanego właśnie. W ten sposób posłuszeństwo wobec władzy zostaje - niebezpiecznie - wydobyte, wyzwolone, uniezależnione od kontekstu zobowiązań tradycyjnych, religijnych i moralnych. Jak uzasadnić tę wolność władzy? Tylko tym, że jest ona konieczna dla tworzenia porzadku życia zbiorowego, gwarantującego bezpieczeństwo i rozwój. Jest to zadanie tym większe, im większy, groźniejszy jest brak owego porządku, im mniejszy jest ład naturalny, im słabszy ład samorzutnie powstający, im większe, bardziej złożone są wymagania, aspiracje, oczekiwania jednostki, poszczególnych grup, społeczeństwa. Zakres

2 Por. J. Attali: 1492, przekład E. Bakowska, M. Pilot, H. Igalson-Tygielska, Czytelnik, Warszawa 1992 , s. $15-110$. 
działań podejmowanych przez państwo wzrasta tym bardziej, im mniej społeczeństwo jest skonsolidowane, im mniej jest wspólnota, im mniej spraw życia zbiorowego jest oczywistych, przesadzonych, bezproblemowych, bezalternatywnych. Dlatego właśnie spójna religijnie, moralnie i obyczajowo społeczność polis nie potrzebowała państwa, władzy suwerennej. Im bardziej społeczeństwo i ustrój polityczny przenikaja się, sa połączone, tym mniej istnieje powodów dla działania poza-, ponadspołecznej instancji władzy i tworzenia państwowego - odgórnego - porząku. W Stanach Zjednoczonych demokracja jest zasada społeczna i zarazem polityczna, podobnie jak prawa człowieka. Tymczasem dla krajów porenesansowej Europy Zachodniej charakterystyczne jest ścisłe rozdzielenie życia społecznego i państwowego. Tu - od XVI wieku - zasadnicze uregulowania doktrynalne i ideowe były wprowadzane moca decyzji władzy państwowej: wyznanie panujące, zniesienie feudalizmu, prawa jednostki, wolność, równość, własność, obywatelstwo...

Co należy do zadań wyłącznych suwerennej władzy? W czym się ona przede wszystkim wyraża? Jean-Louis de Lolme (1741-1804), piszacy o Anglii, w słynnym zdaniu powiada, że suwerenny parlament może czynić wszystko, oprócz uczynienia $z$ kobiety mężczyzny, a $z$ mężczyzny kobiety. Podobnie John Austin (1790-1859) twierdzi, że suwerenna władza może czynić prawie wszystko. Nie brakuje jednak poglądów wskazujących konkretnie na szczególne zadania wyróżniające suwerena. Głoszą one, że jego kompetencje podstawowe polegaja na wskazaniu przeciwnika politycznego, czyli politycznego zła, na zdefiniowaniu interesu narodowego, narodowego bezpieczeństwa, na identyfikowaniu tego, na czym $\mathrm{w}$ określonych sytuacjach polega racja stanu. Potrzeba decyzji i działań suwerennej władzy jest też widoczna w obliczu oczywistych niedostatków rządów merytokracji oraz rządów prawa. Decyzje władzy nie wynikaja bowiem wprost $z$ wiedzy ani norm, $z$ ekspertyz naukowych ani prawnych, nie zastapi ich żadna fachowa, specjalistyczna wiedza (ekspertyz może być wiele, różnych, nie w każdej kwestii moga się pojawić). Potrzebna jest zawsze 
jeszcze - powiada się - decyzja, powzięta tu i teraz, potrzebne jest wzięcie odpowiedzialności, podjęcie ryzyka, dokonanie rozstrzygnięcia... Taki właśnie obowiązek wyróżnia suwerena; obowiazek, do którego spełnienia potrzebna jest na pewno silna wola polityczna, ale nie tylko. Potrzebna jest także znajomość arcana imperii - sztuki rządzenia, sztuki polityki, potrzebny jest zmysł polityczny, który pozwoli dokonać właściwego wyboru, właściwego przesądzenia. Ze względu na co? Na jakie kryteria? - o tym musi postanowić trafnie suweren. Wyjątkowy charakter takiej decyzji polega na pewno na tym, że samo jej podjęcie zmienia sytuację, której ona dotyczy, w której się dokonuje, nie jest czymś oddzielnym, poza nią. Ale nie tylko to. Chodzi bowiem o to, iż nie można pozbawić decyzji tej arbitralności, gdyż nie wynika ona wprost ani $z$ rzeczowych racji, ani $z$ obiektywnych przesłanek; nie można pozbawić jej subiektywizmu, bo podejmujacy ją człowiek występuje wprawdzie $\mathrm{w}$ roli, ma status, działa $z$ urzędu, ale zarazem podejmować ja musi, w tym szczególnym przypadku, on sam, jako konkretna jednostka, osoba, wykazująca Urteilskraft - ludzka władzę sądzenia. Arbitralność, subiektywizm stanowią tutaj istotowe, obiektywne składniki sytuacji decyzyjnej, i dlatego zmieniaja swe znaczenie, przestają być dosłownie arbitralnością i subiektywizmem, zyskuja inny wymiar.

Szczególny rodzaj, charakter rozstrzygnięć ściśle politycznych, fundamentalnych, powoduje, że nie moga one być podejmowane przez każdą władzę, władzę publiczna po prostu, administracyjną. Taka władza bowiem - government/trust - ma $z$ góry określone zadania, ustalone, przewidziane, i im podlega. Charakterystyczne dla nich jest to, że zakładaja "normalna” sytuację; tylko bowiem taka sytuacja daje podstawę, by cokolwiek przewidywać, planować, ustalać, w tym zwłaszcza działania władzy. Polityka w całym tego słowa znaczeniu ma jednak szerszy zakres. Konieczność podjęcia rozstrzygnięć ściśle politycznych wynika $z$ faktu, iż w życiu społecznym pojawiaja się także sytuacje wyjątkowe, możliwe do przewidzenia tylko w bardzo schematyczny, ogólnikowy sposób. Sytuacja wy- 
jątkowa polega między innymi na tym, że „normalny” stan rzeczy nagle przestaje istnieć, że okazuje się, iż nie był on „naturalny”, dany. Zwykła władza publiczna, administracyjna działa w obrębie ustalonej całości życia społecznego, w tych ramach zarzadza powierzonymi sobie sprawami. W momencie, gdy całość ta się rozpada, kompetencje zarządu okazuja się ograniczone, niewystarczające. I wówczas potrzebna jest inna, szczególna instancja władzy, władzy zdolnej odtworzyć lub utworzyć całość życia społecznego oraz jego normalne funkcjonowanie, a także je zagwarantować.

Zadanie władzy suwerennej to utrzymanie całości. Zakłada to ponadspołeczny punkt widzenia, ponadpartykularny, ponadcząstkowy. Całość (jaka? pod jakim względem istniejąca? - to zasadnicze pytanie) jest tą właściwa postacią życia społeczeństwa. Ta potrzeba stanowi racje istnienia podmiotu suwerennej władzy.

Całość polityczna może mieć jeszcze inne, w tym kontekście, znaczenie i inne odniesienie do problemu suwerenności. Mówi o tym współczesny niemiecki teoretyk państwa Ulrich K. Preuss ${ }^{3}$. Suwerenność w czasach absolutyzmu dotyczyła władzy, natomiast w kontynentalnym państwie konstytucyjnym suwerenność ludu dotyczy państwa jako całości. Albowiem pomiędzy ludem a społeczeństwem nie występuje relacja nierówności, nie ma tu więc już miejsca na władzę działająca spoza i sponad społeczeństwa; nadto idea suwerennej władzy ludu jest dziś dobro całości, salus publica. W miejsce różnicy między władzą a społeczeństwem pojawia się więc kategoria całości, jedności (władza ludu, dla ludu, przez lud). Dlatego suwerenność to już dziś nie suwerenność władzy, ale suwerenność państwa jako tej całości, i ta całość jest teraz podmiotem suwerenności, suwerenność ludu zaś to tylko hasło.

Dziś suwerenność nie powinna wcale maleć, bo przecież coraz więcej jest spraw spornych, wymagających rozstrzygnięcia, choćby takiego: czy pozostawić je każdej jednostce $z$ osobna, czy przesa-

\footnotetext{
3 Por. U.K. Preuss: Souveränität. Zwischenbemerkung zu einem Schlusselbegriff des Politischen, w: T. Stein, H. Buchstein, C. Offe (red.): Souveränität, Recht, Moral, Campus Verlag, Frankfurt am Main - New York 2007.
} 
dzić ogólnie, w jednolity sposób. Człowiek jest w stanie dokonać coraz więcej, ma coraz większe możliwości; świat jest coraz mniej swojski, dany, określony, jest coraz bardziej światem interaktywnym, czyli takim, który człowiek sam kształtuje, dobiera składniki, ich ilość, jakość, rodzaj, i komponuje. Świat społeczny jest coraz bardziej ruchomy, dawne tabu już nie istnieja, a przez to życie stało się poniekąd trudniejsze, gdyż można, ale i trzeba decydować o bardzo wielu sprawach, które jeszcze niedawno były oczywiste, przesądzone, bez alternatywy, naturalne, dane. Decydować, wybierać? Na jakiej zasadzie, na podstawie czego? Jakiej wiedzy? Jakiego kryterium?

Na zakończenie tych rozważań warto powrócić do realiów polskich i zwrócić uwagę na fakt, iż w prowadzonych u nas, dość rzadkich dziś mimo wszystko, dyskusjach na temat państwa, jego struktury, przeznaczenia, celów, coś zgrzyta, coś brzmi fałszywie. Słychać to zwłaszcza wtedy, gdy mowa o państwie i suwerenności, o tym, że suwerenność to przymiot, który państwo współczesne traci, który staje się $\mathrm{w}$ obecnych warunkach coraz bardziej anachroniczny, jak maszyna do pisania, lokomotywy parowe i wojny światowe. Ale nawet nie sama teza, że suwerenność jest pojęciem przebrzmiałym, nie na czasie, nieprzynależnym już państwu, zdumiewa i zaskakuje, lecz jej przesłanka. Przyjmuje się bowiem, że suwerenność to zwykła cecha państwa, która może mu przysługiwać lub nie, cecha przypadkowa, niekonieczna, aż tak bardzo przygodna, że państwo może ją utracić niejako w nocy, cichaczem, w sposób niezauważalny dla obywateli. Kreśli się obraz, na którym fale najnowszej historii politycznej wypłukuja suwerenność ze struktury państwa, czynia to nieustannie, niezmiennie, niepostrzeżenie, a jednak w sposób ostateczny, tak że w końcu niespodziewanie okazuje się, iż już jej nie ma. Takie są - twierdzi się - realia, nieubłagane fakty, rozstrzygajace dla każdego, kto chce się liczyć $z$ faktami. Lecz właśnie $\mathrm{w}$ tym ujęciu relacji między suwerennościa a państwem tkwi nieporozumienie. 
Rozważania prowadzone w niniejszym tekście miały właśnie pokazać, że w tradycji państwowości europejskiej za istotne uważa się twierdzenie, iż suwereność jest zasadniczą cechą państwa, cechą struktury politycznej, która ona, jeśli jest państwem, niejako „Z istoty” swej musi posiadać. Twierdzenie to można wyjaśnić, posługując się porównaniem i powołując na autorytet. Oto Immanuel Kant sformułował słynna teze o istnieniu, o której pisał również Martin Heidegger w rozprawie Kants These über das Sein. Kant twierdził mianowicie, że istnienie nie jest zwykła cecha przedmiotu, taka jak bycie podłużnym, ciężkim czy zielonym. Istnienie to coś innego, bardziej podstawowego, w czym rzecz wraz $z$ całościa swych przymiotów się osadza - Position. Otóż niejako to samo można powiedzieć o suwerenności w odniesieniu do państwa - jest to „cecha” szczególna, „wewnętrzna”, to znaczy podstawowa, na której inne sa dopiero nadbudowane, cecha mająca wpływ na inne elementy struktury państwowej, określająca rodzaj bytu, jaki ma byt państwowy, ten choćby, że jest to byt autonomiczny, niesprowadzalny do żadnego innego.

Tymczasem w polskich, wątych zresztą, debatach na temat suwerenności ciagle powtarza się kwestia: przysługuje czy nie przysługuje, a suwerenność jawi się jako przymiot możliwy, ale niekonieczny, jeden $z$ wielu, odrębny, taki, który może być analizowany oddzielnie, bez konsekwencji dla pozostałych, bez zasadniczych konsekwencji dla państwa. $\mathrm{W}$ dodatku w rozważaniach tych samo państwo, pojęcie państwa, pozostaje w cieniu, jako poniekąd znane, przyswojone, nie występujące na pierwszym miejscu, ale tylko jako podmiot, któremu ma być suwerenność przypisana, tak jak przypisana państwu może być każda inna relewantna mu cecha. Uwaga skupiona jest tylko na suwerenności, tak jak gdyby była ona czymś odrębnym od państwa, jest skoncentrowana na niej samej, to ona jest na ceznurowanym, a państwo pozostaje jakby $z$ boku, znane, wiadome, czekajac na przypisanie mu tej cechy lub jej zanegowanie.

Lecz właśnie w tym tkwi błąd, albowiem państwo i suwerenność sa istotowo ze soba powiazane, jedno nie występuje bez drugiego. 
Suwerenność jest cechą wyjątkową państwa, ponieważ jest wyróżniona wśród innych jego cech oraz wyróżniona w stosunku do samego państwa. Jest wyróżniona wśród innych, bo one ją zakładaja, gdyż tylko suwerenne państwo może mieć realne, autentyczne, trwałe cechy, określające jego tożsamość i charakter. Suwerenność jest wyróżniona ze względu na państwo, gdyż dotyka jego sedna, jest najbardziej wewnętrzna jego cecha; nie jest cechą dołączająca się do substancji państwa, ale jej aspektem, innobytem, ma w substancji swe bezpośrednie ugruntowanie. Negacja istotowego zwiazku suwerenności i państwa oznacza tyle samo co stwierdzenie, że samoistny byt nie ma swego rodzaju albo że autonomiczny przedmiot nie ma swej materialnie odrębnej, swoistej przedmiotowości.

Jak powstał ten błędny sposób myślenia, skąd się wzięło to niezrozumienie? Chyba nietrudno to wyjaśnić. Ma on źrodła w niedawnej przeszłości naszego kraju i sposobie jej pojmowania. Niezmiennie przecież o PRL-u mówi się właśnie, że był państwem niesuwerennym: istniał PRL, ale suwerenności nie posiadał, był państwem zależnym, podległym, choć stopień zależności może się zmieniał. Istniało więc państwo bez suwerenności, suwerenność zaś pojawiła się dopiero później, została niejako dodana do tego, co istniało już wcześniej i pozostało. Potwierdzaja to oczywiste fakty. Czy jednak aby na pewno?

Owszem, istnienie PRL-u było faktem oczywistym, ale czym był ten fakt, czym był PRL? Czy to fakt istnienia państwa, czy też fakt istnienia pewnego, trudnego do określenia ustroju politycznego? Państwowość PRL-u stanowi poważny problem badawczy i nie tylko. Fakty, zwłaszcza tak skomplikowane, wieloczynnikowe, kompleksowe jak istniejace struktury polityczne, „same” nie wszystko rozstrzygaja, trzeba je bowiem dopiero właściwie odczytywać, identyfikować, rozumieć. Trzeba odnaleźć ich rodowód, przyporząkować je pojęciom historycznym, mającym swoją specyficzną semantykę, pojęciom, które nie sa pojęciami naturalnej władzy poznawczej: czystego rozumu lub intelektu, ale pojęciami „rozumu komunikacyjnego”, należącymi do sfery publicznej, do dyskursu politycznego. 
PRL pozostawił na państwie odium, ale też i przekonanie, że może istnieć państwo bez suwerenności, że sa to rzeczy oddzielne. Tak jednak nie jest. Suwerenność nie jest dodatkiem do państwa, który może ono posiadać lub nie, zależnie od okoliczności, dodatkiem, którego może być pozbawione, a potem znów niespodziewanie go odzyskać. Dopóki nie postaramy się zrozumieć, czym jest suwerenność, państwowość i ich związek, dopóki nie wytłumaczymy sobie, że PRL - jako niesuwerenny - państwem rzeczywistym nie był (choć oczywiście był pewnym ustrojem politycznym - na przykład ustrojem realnego komunizmu), że trzeba zatem budować państwo polskie od nowa, od podstaw, wedle innych typów idealnych, od nowa na każdym piętrze gmachu państwa, dopóty będziemy błąkać się w myśleniu i gubić w pojęciach.

Oczywiście, wolni obywatele nie sa skazani na państwo ani na suwerenność, moga chcieć budować inny ustrój. „Konieczna” struktura państwa i jego istotowy związek $z$ suwerennościa nie sa „prawami natury", którym, czy się tego chce, czy nie, trzeba się poddać. „Konieczność” jest tutaj... relatywna, bo oznacza wewnętrzną logikę i racjonalność pewnego ludzkiego tworu powstałego $\mathrm{w}$ historii, na potrzeby życia społecznego. Jeśli jednak uznajemy go za osiagnięcie, za wytwór kultury, „wynalazek Europy”, to warto - wręcz trzeba - poznać głębiej jego „naturę”, jego rodzajowa indywidualność, tak jak krytyk sztuki poznaje walory dzieła, które udało się - nie wiadomo do końca jak - stworzyć artyście. Trzeba poznać, by zrozumieć, docenić, zdobyć wiedzę o samym człowieku jako twórcy, o życiu zbiorowym, o historii... Wiedza ta jest ważna i potrzebna, jeśli uważamy, że, przynajmniej w jakiejś mierze, historia magistra vitae est, jest potrzebna, abyśmy wiedzieli, jakie podejmujemy ryzyko, jeśli naprawdę chcemy pogrzebać, odrzucić państwo suwerenne. Jest też potrzebna, abyśmy nie czuli się aż tak bardzo panami dziejów, panami naszej historii, gdyż to faustowskie poczucie skłania nas do czynów kategorycznych, zbyt śmiałych, zbyt daleko idących, takich, które właśnie tworzą historię, ale - jak się później okazuje - nieodgadnioną, obezwładniającą, groźną. 